\title{
Transition to Solar Energy Using Rooftop of Public Buildings in Palestine
}

\author{
Ibrik Imad $^{1}$, Hashaika Fadia ${ }^{2}$ \\ 1,2 Energy Research Center \\ An-Najah National University \\ Nablus,Palestine
}

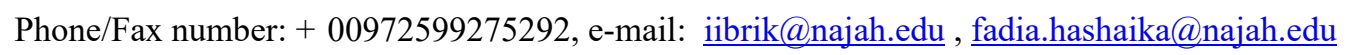

\begin{abstract}
This paper presents a study for $(20 \mathrm{kWp})$ gridconnected solar PV systems installed on the roof top of municipalities in different cities in Palestine, using actual monitored data that extracted from project portal and compare the result with PV-syst software result which provide a comprehensive study of the system design and detailed analysis for performance of systems under a local climate conditions. The supplied grid energy and main performances are described, and the effects of losses of the inverter to the grid have been studied. The performance, CUF and yield parameters were studied using the monitored data of year 2018 in different location at west bank. The PV system generated 36.2 MWh in average during the year 2018. The average final yield ranged from 5.35-5.5 kWh/kWp-day, PR ranged from $74-89 \%$ and annual CUF varies between $16-20 \%$. The findings from this study are useful in identifying solar performance and provide useful information to policy makers and individuals about the performance of grid-tied PV system in different cities in Palestine.
\end{abstract}

Key words. Grid connected PV system, Performance indicators; Techno - economic feasibility, Municipalities, Palestine.

\section{Introduction}

Currently, Palestine suffering a lot at lack of conventional supply, this problem have forced government to think more deeply about the alternative sources of energy to substitute the conventional sources of supply. Solar PV now is a popular source of energy in Palestine, both on the utility's side and for roof top governmental, commercial and residential home use $[1,2]$. Solar Photovoltaic (PV) systems is a good alternative and feasible solution for generating electricity in Palestine, especially for grid connected systems. The potential of solar radiation is about $5.4 \mathrm{kWh} / \mathrm{m}^{2} /$ day with about 3000 sunshine hours a year [3][6]. PV-grid connected systems are worldwide installed because it allows consumer to reduce energy consumption from the electricity grid and to feed the excess energy back into the grid. The system does not contain battery; therefore the overall system cost and maintenance are very cheap comparing to other PV systems types [7]. When planning to implement a new solar project, the requirements and the specifications of the photovoltaic panel are usually unclear, incomplete and not integrated with design process and if the project was implemented and errors are detected at this point is already too late, and in that case we have to redesign or make a very expensive tests in order to reduce negative results, so the performance evaluation of PV systems is an important measure to help identify the future needs of research, development and test the system before implementation to get an estimated results for operation and output. Using appropriate performance parameters facilitates the assessment of energy efficiency of PV systems connected to the grid which can be affected by design, technology used or geographic location. However, in order to ensure the safety of PV installer and reliability of the utility grid, the technical requirement for the grid and the PV system must be achieved to prevent any problems, such as harmonic distortion and electromagnetic interference [1].The need to choose PV modules and inverters have become necessary due to the diversity of technology and in order to determine the system behaviour, but knowing the extent of efficiency of the system is a very difficult, therefore, PV system can be evaluated by investigating the performance ratio (PR) which defined by ratio of the system efficiency and nominal efficiency of PV module under STC [8].In fact, growing the electricity generation by PV units is one of the highest in the field of renewable energies and this tendency is expected to continue in the next years. As obvious, an increasing number of new PV components and devices, mainly arrays and inverters are coming onto the PV markets. This paper aims to investigate the performance of $20 \mathrm{kWp}$ that located in different location on rooftop of 7 municipalities buildings in different cities at West Bank - Palestine. The performance is studied during the monitored period of one year 2018. The PV system performance is characterized using different parameters: reference yield, final yield, capacity utilization factor, and system efficiency and performance ratio. Then the paper present a comparison between actual measured and predicted performance using PV simulation software as PVsyst, this study offers a baseline information to enhance Mono-crystalline PV performance and reduced cost.

\section{Description of Solar PV Grid System}

The seven $20 \mathrm{kWp}$ grid-connected PV systems under investigation were installed on roof-top of seven 
municipalities at West Bank - Palestine. Each system has 64 Mono-crystalline modules of $320 \mathrm{Wp}$ to get overall installed capacity of $20.48 \mathrm{kWp}$, covering a total surface area in each building of $120 \mathrm{~m} 2$, and inclined at 32 degree toward the south. The PV modules are arranged to 4 parallel strings with 16 modules in each string and connected to two 3phase inverters (Sunny Tripower 10000TL) to convert DC energy generated by $\mathrm{PV}$ array to AC energy as shown in Fig.1, 2. The inverter enclosure is IP65 which offer complete protection from particles and a good level of protection against water, so practically, it can install indoor and outdoor without affect the inverter operation. The installed inverter has maximum efficiency of $98 \%$, with rated power $10 \mathrm{~kW}$ for $230 \mathrm{~V}, 50 \mathrm{~Hz}$ on $\mathrm{AC}$ grid side, Tables. 1 and 2 show the specification of power plant.

Table 1. PV module specification

\begin{tabular}{|l|l|}
\hline Number of panel & 64 \\
\hline PV Brand & Amerisolar \\
\hline model No. & AS-6M 320 \\
\hline Wp/panel & $320 \mathrm{Wp}$ \\
\hline System capacity & $20.48 \mathrm{kWp}$ \\
\hline $\begin{array}{l}\text { Voltage at Maximum Power } \\
\text { (Vmpp) }\end{array}$ & 37.1 \\
\hline $\begin{array}{l}\text { Current at Maximum Power } \\
\text { (Impp) }\end{array}$ & 8.63 \\
\hline Open Circuit Voltage (Voc) & 45.7 \\
\hline Short Circuit Current (Isc) & 9.00 \\
\hline Panel Efficiency (\%) & 16.49 \\
\hline Cell Type & Mono-crystalline \\
\hline Panel dimension (m) & $1.956 \times 0.992 \times 0.05 m$ \\
\hline Panel area (m2) & 1.94 \\
\hline Panel weight (Kg) & 27 \\
\hline
\end{tabular}

Table 2. Inverter specification

\begin{tabular}{|l|l|}
\hline System capacity & $20 \mathrm{~kW}$ \\
\hline Brand & SMA \\
\hline Model No. & $\begin{array}{l}\text { Sunny Tripower } \\
10000 \mathrm{TL}\end{array}$ \\
\hline NO. of independent MPP inputs & 2 \\
\hline $\begin{array}{l}\text { DC MPPT Range/Input voltage } \\
\text { range }\end{array}$ & $370-800 \mathrm{~V}$ \\
\hline Max input current (DC) / string & $18 \mathrm{~A} / 10 \mathrm{~A}$ \\
\hline Rated AC power (W) & 10,000 \\
\hline AC voltage range & $160-280 \mathrm{~V}$ \\
\hline Max output current & $14.5 \mathrm{~A}$ \\
\hline Efficiency (\%) & $97.6 \%$ \\
\hline Weight & $37 \mathrm{~kg}$ \\
\hline No. of inverter per project site & 2 \\
\hline
\end{tabular}
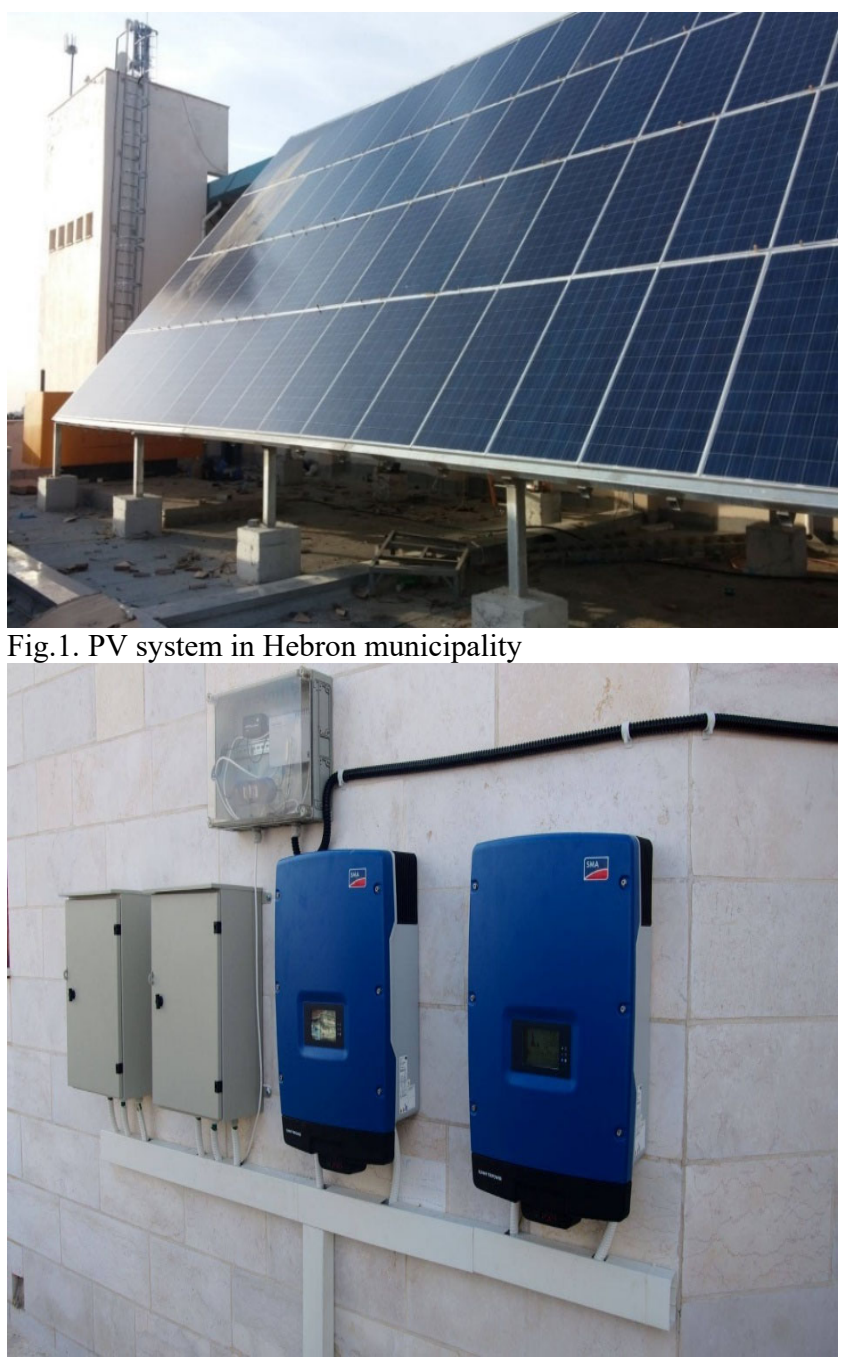

Fig.2. Out-door Sunny Tripower Inverter

\section{Performance Analysis of PV Systems in Different Cities}

The performance of grid connected solar PV power plant was displayed in this paper in 2 stages:

(1) Manually extract the monitored data of power generation through remote monitoring system using online portal , (2) Compare the performance with PVsyst software result This performance parameters are developed by International Energy Agency (IEA) [9, 10], for analyzing the performance of solar PV grid interconnected system.

Array yield (YA)

Array yield of the system is the ratio of annual/monthly/daily energy output to the installed capacity of PV system.

$Y_{A}=\frac{E_{A}}{P_{\circ}}$

EA: Array DC energy yield per day $\mathrm{P}^{\circ}$ : Nominal power at STC

This parameter shows the time which operated by PV array per day

Reference yield (YR) 
$Y_{R}=\frac{H_{t}}{G_{\circ}}$

Ht:total horizontal irradiance on array plane $\left(\mathrm{Wh} / \mathrm{m}^{\wedge} 2\right)$

$\mathrm{G}^{\circ}$ : Global irradiance at STC $\left(\mathrm{W} / \mathrm{m}^{\wedge} 2\right)$

This parameter refers to number of peak sun hours

Final yield (YF)

The final yield or called yield factor (YF) is the ratio of the net AC energy of the system, at standard testing conditions, and the peak power of PV system installed [11], the net energy can be annual, monthly or daily and it is calculated as in $\mathrm{Eq}(3)$.

$Y_{F}=\frac{E_{A C}}{P_{M A X, S T C}}$

$E_{A C}: A C$ Enegy yield of $P V$ system

$P_{M A X, S T C}:$ Peak power of installed PV systrm at STC

Performance Ratio (PR)

Concerning the performance ratio (PR), it represents the ratio of energy fed to the grid (final yield) to the energy that the system could have produced when it operated at its rated conditions (STC) of $1 K W / \mathrm{m} 2$ (reference yield) [12]. PR represents the fraction of energy actually available after deducting energy losses. PR is given by Eq (4).

$P R=\frac{Y_{f}}{Y_{R}} * 100 \%$

Capacity utilization factor (CUF)

CUF is annual factor comparison between actual output and PV energy output if it is operated at full rated power for 24 hours all year [13]. This factor is used in assessing the PV array usage. The equation of capacity factor is shown in Eq (5).

$C U F=\frac{\text { Energy measured }(k w h)}{365 * 24 * \text { installed capacity of } P V}$

Inverter efficiency ( $\eta$ inverter)

Inverter efficiency can be defined based on the amount of electrical DC power delivered to the inverter from the PV generator (PDC) and the AC power obtained from the inverter (PAC) [14] .The instantaneous inverter efficiency ( $\eta$ inv) is defined as the ratio of output to input power and calculated as in Eq (6).

$\eta_{\text {inverter }}=\frac{P_{A C}}{P_{D C}}$

System efficiency ( $\eta$ (sys))

The system efficiency is calculated as in $\operatorname{Eq}(7)$.

$\eta_{\text {sys total }}=\eta_{P V} * \eta_{\text {inverter }}$
This factor measures the conversion efficiency of inverter under operation condition.

Solar Fraction (SF)

The solar fraction is calculated as in $\mathrm{Eq}(8)$.

$S F=\frac{\text { Energy measured }(k w h)}{\text { site energy load }(K w h)}$

This factor measures how much energy the PV system will cover of load-penetration factor.

\section{Results and discussion}

The results of performance analysis of measured data for the seven PV systems are discussed in this section.

The monthly energy outputs result shows as indicated in Table. 3 that the maximum energy output was in Baqa Alsharqia in April 2018 (3514 kWh/month) and minimum in February $2018(1800 \mathrm{kWh} /$ month $)$ in Alittihad municipality as shown in Fig.3. The annual overall system efficiency varies from $7-23 \%$ as indicated in Fig.8.

Table 3. AC monitored energy yield at seven project location

\begin{tabular}{|c|c|c|c|c|c|c|c|}
\hline & \multicolumn{7}{|c|}{ Energy AC (kWh/month) } \\
\hline M & Hebron & Nablus & $\begin{array}{c}\text { Thaheri } \\
\text { ya }\end{array}$ & Qabalan & $\begin{array}{c}\text { Baqa } \\
\text { Alsharqi }\end{array}$ & Anata & Alittihad \\
\hline 1 & 2354.89 & 1983.509 & 2036.85 & 2268.81 & 2404.87 & 2484.87 & 2136.8 \\
\hline 2 & 2688.55 & 2359.86 & 2626.94 & 2451.58 & 2680.92 & 2600.96 & 1800.23 \\
\hline 3 & 2740.73 & 2499.309 & 2784.56 & 2689.80 & 3011.28 & 2961.7 & 2587.556 \\
\hline 4 & 2557.56 & 2996.669 & 2690.31 & 3173.74 & 3513.87 & 3330.89 & 3145.714 \\
\hline 5 & 2647.95 & 2905.519 & 3158.03 & 3164.97 & 3321.32 & 3376.44 & 3240.054 \\
\hline 6 & 2427.17 & 3068.757 & 2809.26 & 3080.08 & 3074.47 & 3246.21 & 3140.4 \\
\hline 7 & 2441.95 & 2990.89 & 2673.05 & 2965.95 & 3283.28 & 3165.98 & 2894.212 \\
\hline 8 & 2376.33 & 2972.006 & 2525.10 & 3070.15 & 3212.79 & 3255.46 & 2415.592 \\
\hline 9 & 3006.81 & 2835.877 & 3183.59 & 2632.75 & 2940.28 & 2895.57 & 2411.702 \\
\hline 10 & 2845.13 & 2637.027 & 2963.41 & 2647.94 & 2768.04 & 3003.18 & 2840.128 \\
\hline 11 & 2517.33 & 2124.988 & 2289.15 & 2344.67 & 2311.88 & 2445.79 & 2303.782 \\
\hline 12 & 2443.48 & 1975.391 & 1850 & 2164.53 & 2638.43 & 2332.46 & 1817.79 \\
\hline Tot & 31047.9 & 31349.8 & 31590.2 & 32655.0 & 35161.4 & 35099.5 & 30733.96 \\
\hline Max & 3006.82 & 3068.757 & 3183.59 & 3173.74 & 3513.87 & 3376.44 & 3240.054 \\
\hline Min & 2354.89 & 1975.391 & 1850.00 & 2164.53 & 2311.88 & 2332.46 & 1800.230 \\
\hline
\end{tabular}

PV system energy AC yield (KWh/month)

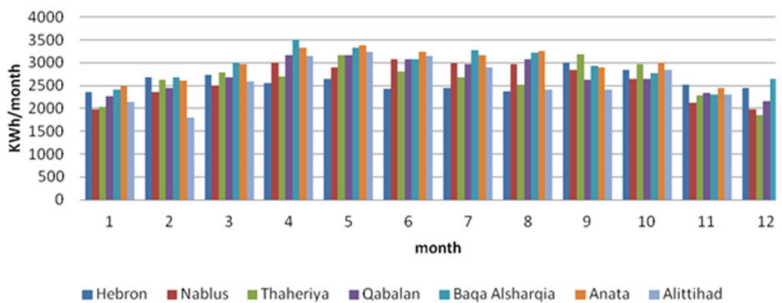

Fig. 3. PV system AC energy production

The annual average monthly performance ratio varies between $74 \%-89 \%$, and CUF factor has minimum annual average monthly in Hebron (16.3\%) and maximum value in Baqa alsharqia of $20.1 \%$ as shown in Fig.8.Regarding final yield and solar fraction, the result shows as in Fig.5 and Fig.7 that the highest final yield in all site were observed in summer due to clear sky in most of monthly day and the overall highest value of $5.719 \mathrm{kWh} / \mathrm{kW}$ was observed during April in Baqa Alsharqia, but the minimum PV system operated hours were mostly in December (winter season), and thus the penetration/solar factor of PV system is higher in summer in comparative to winter season because it depends on number of operated 
PV system hours per day.The system performance changed due to weather, in cold weather the PR and system efficiency was observed and its value varies $85-92 \%$ due to lowest final yield and the maximum system efficiency was $16.3 \%$ and this due to low ambient temperature which prevent module to reach high temperature. But in summer, the operated hours of system has increased which cause the performance ratio to be low and reach $72-77 \%$.Fig. 4 shows the average system production versus solar irradiance.

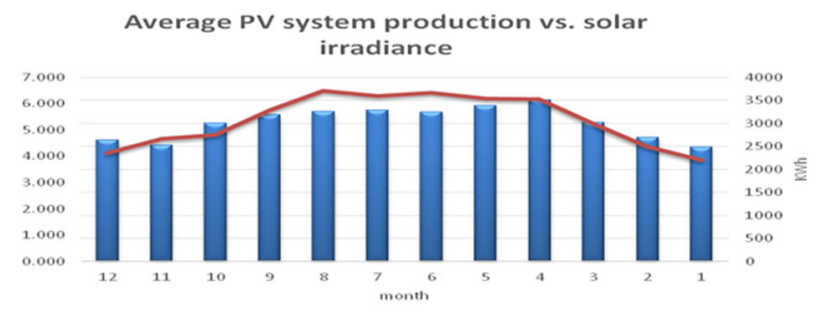

Fig. 4. Average PV system production vs. solar irradiance

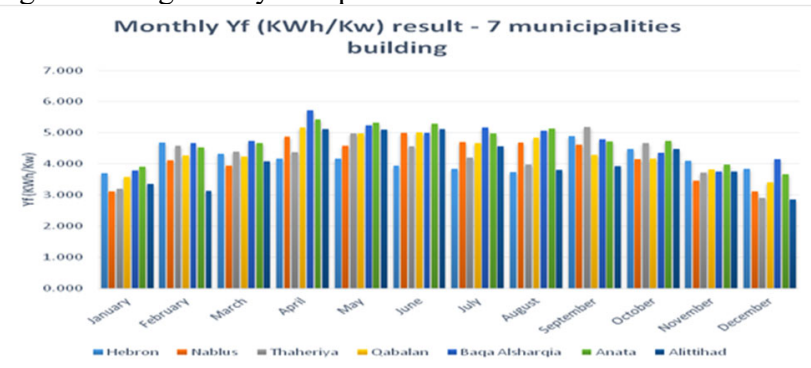

Fig. 5.Monthy average final yield

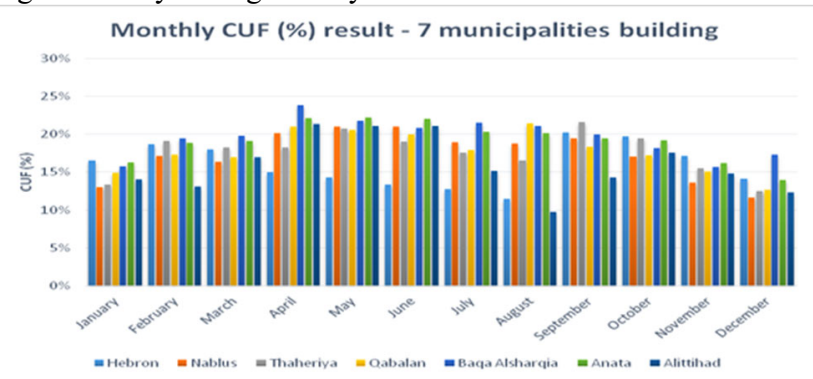

Fig.6. Monthly average capacity utilization factor

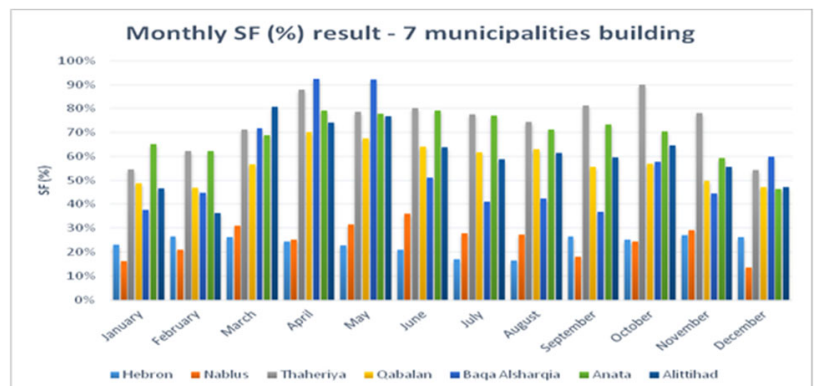

Fig. 7.Monthly average solar fraction

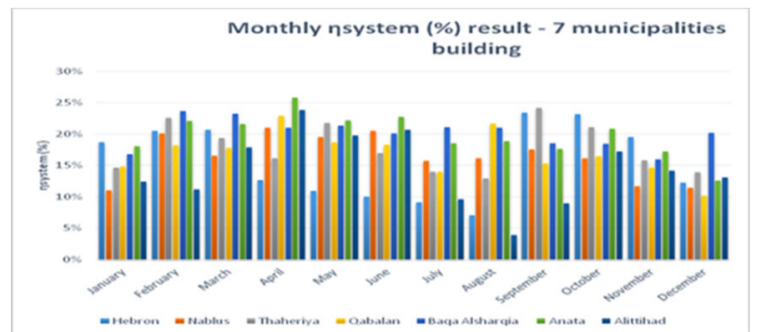

Fig.8.The annual overall monthly system efficiency

\section{Simulation Results vs. Actual Output}

A number of simulation software are developed to predict the performance of a solar power plant and easily to assist designers and installers [15]. In this study, PVsyst software is used to predict the performance parameters and energy output of $20 \mathrm{kWp}$ grid-connected power plants. PVsyst was design for studying, sizing and data analyzing of photovoltaic grid-connected, stand-alone and water pumping systems. The PVsyst simulations inputs involve meteorological data, modules and inverters specifications. The system was simulated to estimate the performance of solar power plant and predicts the system output using meteo data from many resource as well as a personal data. The total amount of energy that injected to grid for a year is $39.126 \mathrm{MWh}$. the maximum energy output is $3868 \mathrm{kWh}$ of October and minimum energy output in January is 3022 kWh.as indicated in Fig.9. The actual energy generated by the array is $40879 \mathrm{kWh} /$ year before losses about 1753 $\mathrm{kWh} /$ year.

Table 4. Balances and main results

\begin{tabular}{|c|c|c|c|c|c|c|c|c|}
\hline & GlobHor & TAmb & Globline & GlobEF & EArray & E_Grid & EffArrR & EffSysR \\
\hline & $k W h / m^{2}$ & ${ }^{\circ} \mathrm{C}$ & $\mathrm{kWV} / \mathrm{m}^{2}$ & $\mathrm{kWh} / \mathrm{m}^{2}$ & $\mathrm{kWh}$ & kWh & $\%$ & \\
\hline January & 114.0 & 7.90 & 175.6 & 171.0 & 3156 & 3022 & 17.22 & 16.49 \\
\hline February & 124.0 & 8.40 & 166.5 & 162.4 & 2974 & 2848 & 17.11 & 16.39 \\
\hline March & 166.0 & 10.70 & 194.0 & 188.6 & 3426 & 3278 & 16.92 & 16.19 \\
\hline April & 184.0 & 15.10 & 186.1 & 180.5 & 3221 & 3081 & 16.58 & 15.86 \\
\hline May & 210.0 & 19.00 & 191.2 & 185.1 & 3254 & 3113 & 16.30 & 15.60 \\
\hline June & 219.0 & 21.20 & 188.6 & 1822 & 3167 & 3029 & 16.09 & 15.39 \\
\hline July & 223.0 & 22.90 & 196.7 & 189.9 & 3282 & 3140 & 15.99 & 15.29 \\
\hline August & 221.0 & 23.40 & 214.6 & 207.9 & 3577 & 3422 & 15.97 & 15.28 \\
\hline September & 202.0 & 22.30 & 227.1 & 221.0 & 3818 & 3656 & 16.11 & 15.42 \\
\hline October & 177.0 & 19.00 & 236.4 & 230.5 & 4039 & 3868 & 16.37 & 15.68 \\
\hline November & 136.0 & 14.50 & 209.7 & 204.6 & 3638 & 3483 & 16.62 & 15.92 \\
\hline December & 114.0 & 9.50 & 186.5 & 182.0 & 3328 & 3188 & 17.09 & 16.38 \\
\hline Year & 2090.0 & 16.20 & 2372.9 & 2305.7 & 400879 & 39126 & 16.51 & 15.80 \\
\hline
\end{tabular}

According to Table 4. The annual global horizontal irradiation is $2090 \mathrm{kWh} / \mathrm{m} 2$, the global incident energy on the collector plane annually is $2372.9 \mathrm{kWh} / \mathrm{m} 2$. The total energy obtained from output of PV array is 40.879 MWh.

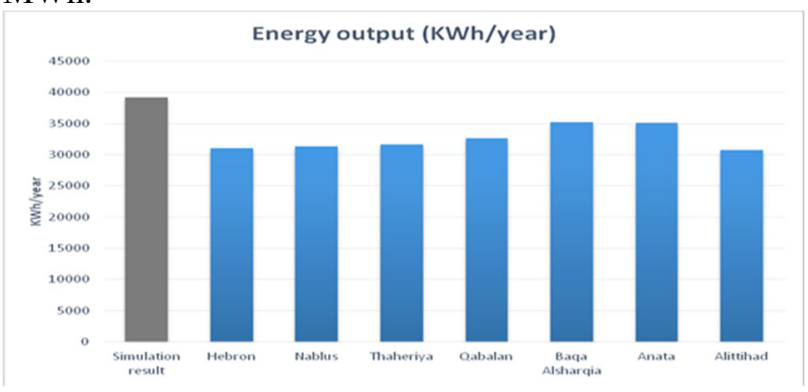

Fig.9.Simulated energy output results compared with real results

The annual average performance ratio is $82 \%$, this value has not much difference with actual performance ratio.

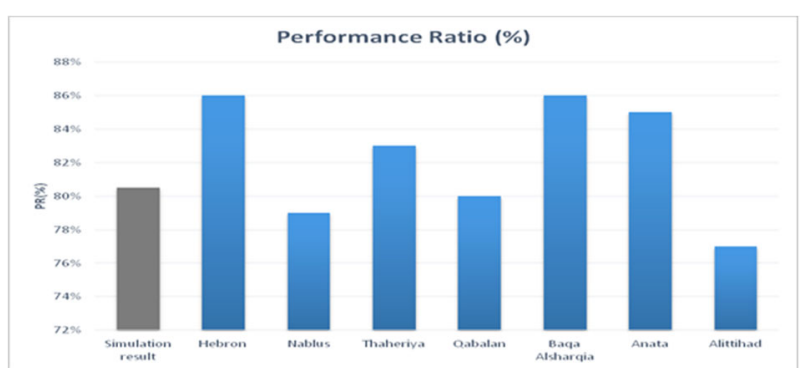

Fig.10.Simulated performance ratio results compared with real results 
For the loss diagram over the whole year, the results shown the largest losses were because of the temperature around $5.6 \%$, the horizontal global irradiance is $2090 \mathrm{kWh} / \mathrm{m} 2$ and the effective irradiance on collectors is $2306 \mathrm{kWh} / \mathrm{m} 2$ which means the total energy for the area of $104 \mathrm{~m} 2$ is $239.8 \mathrm{MWh}$, the efficiency of the system equal to $19.7 \%$, and the array nominal energy at STC is $47.3 \mathrm{MWh}$.

The measured average result from SMA portal from 7 locations in WestBank-Palestine is compared with PVSyst software result, are presented in Fig. 11.

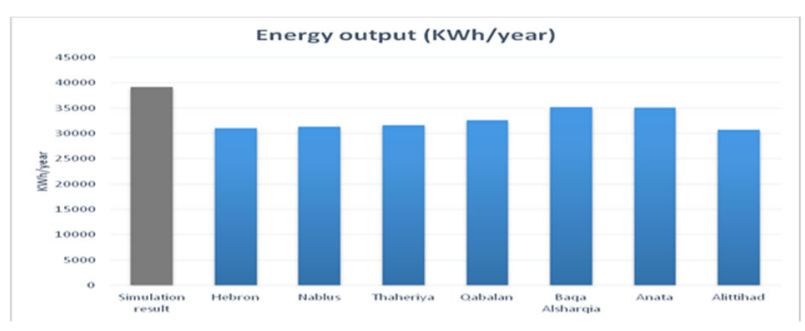

Fig.11. Simulated energy eutput results compared with SMA monitored results

\section{Economic analysis}

After investigating the technical performance, it is necessary to pursue an economic analysis. The feasibility of system must be also determined. The aim of the financial analysis is to determine and compare the profitability of the construction of the PV plant. The financial analysis of the PV plant gives an evaluation of potential additional or rising income and costs. To identify the effect of installing PV solar system, we calculate the payback time, capital cost, financial saving [2].

\section{A. Simple Payback Period}

The payback time depends on the price of equipment cost which includes Photovoltaic panel, inverters, cabling, connectors, frame price and labour cost which includes planning cost, assembly, commissioning cost, permit cost as well as interest rate. SPBP is simple calculated as in Eq (9).

$$
\text { S.P.B.P }=\frac{\text { Investment cost }}{\text { saving cost per year }}
$$

The SPBP for each municipality is shown in Fig.14.

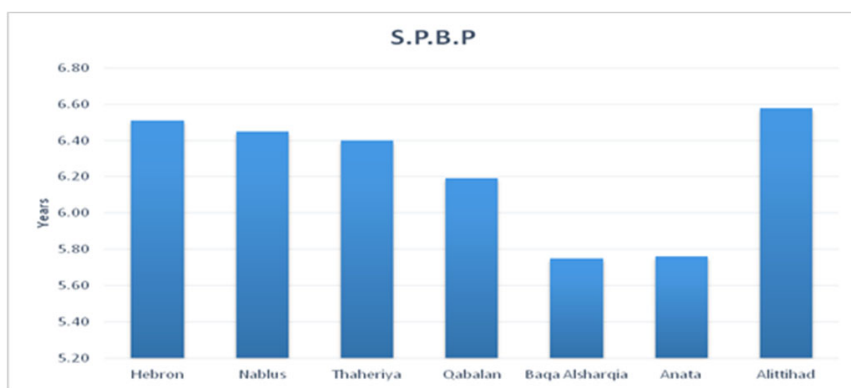

Fig.12.Simple payback period for each municipality

Annual AC energy production of $20 \mathrm{~kW}$ system $=$ $36,202.52 \mathrm{kWh} /$ year and the saving cost $(\$)=3,982.3$ US\$/year as shown in Table 5.
Table 5. Financial saving

\begin{tabular}{|l|c|c|}
\hline \multicolumn{2}{|c|}{ System capacity $=20 \mathrm{kWp}$} & \multirow{2}{*}{ Saving (\$) } \\
\hline Month & E out $(\mathrm{kWh})$ & 273.33592 \\
\hline January & 2484.872 & 295.74127 \\
\hline February & 2688.557 & 331.2408 \\
\hline March & 3011.28 & 386.52636 \\
\hline April & 3513.876 & 371.40862 \\
\hline May & 3376.442 & 357.0831 \\
\hline June & 3246.21 & 361.16102 \\
\hline July & 3283.282 & 358.1006 \\
\hline August & 3255.46 & 350.19512 \\
\hline September & 3183.592 & 330.3498 \\
\hline October & 3003.18 & 276.90674 \\
\hline November & 2517.334 & 290.22774 \\
\hline December & 2638.434 & 3982.27709 \\
\hline
\end{tabular}

- $\quad$ PV Investment cost $=22,240$ US\$

- $\quad$ Average S.P.B.P $=5$ years \& 7 month.

\section{B. NET Present Value/ Cash Flow}

The cash flow diagram is shown in Fig.13.

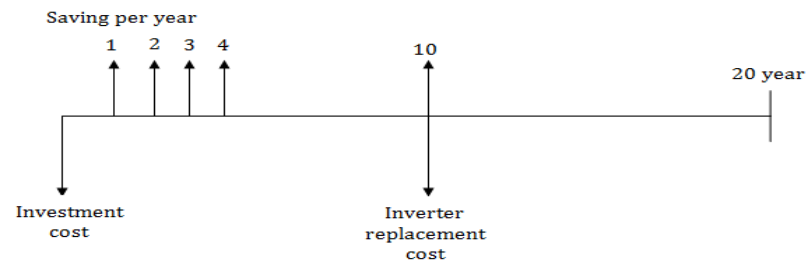

Fig. 13. Cash flow diagram

To find equivalent present value as in Eq (10), when $\mathrm{i}=$ $10 \%$ and $n=20$ years.

$\mathrm{NPV}=$ Income cash flow - Outcome cash flow

The average NPV value is $11,053.52(>0)$, so the project is feasible, Fig. 14 shows the NPV foe each municipality.

\section{Internal Rate of Return (IRR)}

The IRR is calculated as in Eq (11)

$$
\begin{aligned}
& 0=\mathrm{NPV}=\mathrm{P} 0+\mathrm{P} 1 /(1+\mathrm{IRR})+\mathrm{P} 2 /(1+\mathrm{IRR}) 2+\mathrm{P} 3 /(1+\mathrm{IRR}) 3 \\
& +. .+\mathrm{Pn} /(1+\mathrm{IRR}) \mathrm{n}
\end{aligned}
$$

Where $\mathrm{P} 0, \mathrm{P} 1, \ldots$ Pn equals the cash flows in periods 1 , $2, \ldots$ n, year respectively; and IRR equals the project's internal rate of return and NPV $=$ Zero.

Internal Rate of Return (IRR) is $16.8 \%$.

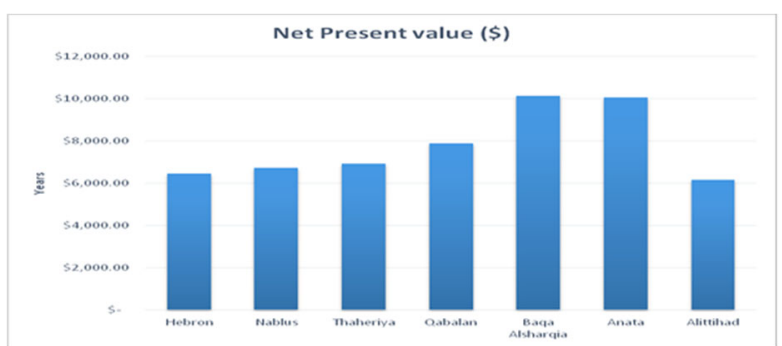

Fig.14.Net present value for each municipality. 


\section{Conclusion}

Comparative Analysis of Measured and Simulated Performance of grid-connected solar photovoltaic (PV) system in the Rooftops of different cities in Palestine, for this research study we used a convenience sample of seven systems for simulation and analysis the impact of installing a rooftop solar PV technology. The $20 \mathrm{kWp}$ grid-connected $\mathrm{PV}$ power plants was monitored during the year of 2018 and its monthly and annual performance parameters were evaluated and compared with simulated parameters. The simulation results gave a good approximation to measured energy output and irradiation; however, the simulation is less accurate when it comes to the ambient air temperature particularly in April, May and July when temperature increases in the region. The results show a rooftop solar photovoltaic potential and the impact of installing $20 \mathrm{~kW}$ on the roof top of public buildings.

The following conclusion was obtained from the study:

- The systems are operated with losses of 7\% from predicted generation of PVSyst software

- The annual average penetration factor is found to be 24$74 \%$ of building load

- The average final yield per year is $1817 \mathrm{kWh} / \mathrm{KW}$ of $20 \mathrm{kWp}$ system in West bank-Palestine

- The average annual performance ratio was found $82 \%$

- The average annual capacity factor was found $18 \%$.

- In the analysis, we used 5 performance indicator to study the PV system efficiency

- The indicators were grouped into two groups:

- 1st group: include the factors which depends on studying the system output to ideal/load condition (SF, CUF, Final yield) and this show that the maximum performance occurs in summer

- 2nd group: include (PR, System efficiency) which taking into consideration system component efficient and irradiance changed and the comparison show that the maximum performance was in winter due to reduction of thermal losses.

- The result show the average of reduction $\mathrm{CO} 2$ emission about $27,151 \mathrm{~kg}$ per year

- Financial performance indicators (payback period, internal rate of return (IRR), and net present value (NPV) were analyzed for the PV system. The main income of the project is provided by selling the generated electricity to the distribution company. Fig. 15 explains the cumulative cash flow of the project during the lifetime of the project which is expected to be around 20 years. The payback period is expected to be ranged from 5-6 years and the Net Present Value (NPV) is about $\$ 11,053.52$. The Internal Rate of Return (IRR) for the project during a 20-year lifespan is about $16.8 \%$.In this paper we aim to encourage the decision makers to install solar PV on the roof top of any public buildings and schools in Palestine to collect the solar energy as the alternative source of electricity for covering their electricity demand.

\section{References}

[1] Ibrik Imad, 2019, Power Quality and Performance of GridConnected Solar PV System in Palestine, International Journal of Engineering Research and Technology. Volume 12, Number 9 (2019), pp. 1500-1507.

[2] Ibrik, I, Hashaika, F, 2019. Techno-economic impact of gridconnected rooftop solar photovoltaic system for schools in palestine: A case study of three schools, International Journal of Energy Economics and Policy, 2019, 9(3), 291-300.

[3] Ibrik, I. (2007). Potential of renewable energy in Palestine. Paper presented at the Conference on Energy and Environmental Protection in Sustainable Development", Hebron, West Bank, May 8-9.

[4] Imad H Ibrik. 2019. An overview of electrification rural areas in Palestine by using micro-grid solar energy, Journal Cogent Engineering, Volume 6, 2019 - Issue 1.

[5] Ibrik, I, 2019. Design and Verification the Results of Electrification Small Communitiesin Palestine by Using Decentralized Off-Grid PV Systems, International Journal of Innovative Technology and Exploring Engineering (IJITEE), Volume-8 Issue-9, 983-987.

[6] Imad Ibrik, 2019. Modeling the Optimum Solar PV System for Management of Peak Demand, International Journal of Energy Economics and Policy, 2019, 9(2), 246-250.

[7] Ayompe, L.M., Duffy, A., McCormack, S.J., Conlon, M., 2011. Measured performance of a $1.72 \mathrm{~kW}$ rooftop grid connected photovoltaic system in Ireland. Energy Converse. Manage. 52, pp. 816-825.

[8] Marion, B., Adelsten, J., Boyel, K., Hayden, H., Hammon, B., Fletcher, T., Canada, B., Narang, D., Kimber, A., Michell, L., Rich, G., Towsend, T., Detride, A., Kimbler, A., 2005. Performance parameters for grid-connected PV system. In: Proceeding of the 31 st IEEE Photovoltaic Specialist Conference, Lake Buena Vista FL, pp. 1601-1606.

[9] Sharma, Vikrant, Chandel, S.S., 2013. Performance analysis of a $190 \mathrm{kWp}$ grid interactive solar photovoltaic power plant in India. Energy 55, pp. 476-485.

[10] B. Shiva Kumar, K. Sudhakar, 2015. Performance evaluation of $10 \mathrm{MW}$ grid connected solar photovoltaic power plant in India. Energy Reports 1, pp. 184-192.

[11] Kamal Attari, Ali Elyaakoubi, Adel Asselman, 2016. Performance analysis and investigation of a grid-connected photovoltaic installation in Morocco. Energy Reports 2, pp. 261266.

[12] Renu Sharma, Sonali Goel, 2017. Performance analysis of a $11.2 \mathrm{kWp}$ roof top grid-connected PVsystem in Eastern India. Energy Reports 3, pp. 76-84.

[13] Akash Kumar Shukla, K. Sudhakar, Prashant Baredar, 2016. Simulation and performance analysis of $110 \mathrm{~kW}$ grid-connected photovoltaic system for residential building in India: A comparative analysis of various PV technology. Energy Reports 2, pp. 82-88.

[14] K. Attari, A. Elyaakoubi, and A. Asselman. (2016) .Performance analysis and investigation of a grid-connected photovoltaic installation in Morocco," Energy Reports, vol. 2, pp. 261-266.

[15] Merrouni A.A., Ait lahousine O.H, Moussaoui M.A, Mezrhab A.; International Journal of Renewable Energy Research. 6 (2016) 1. 